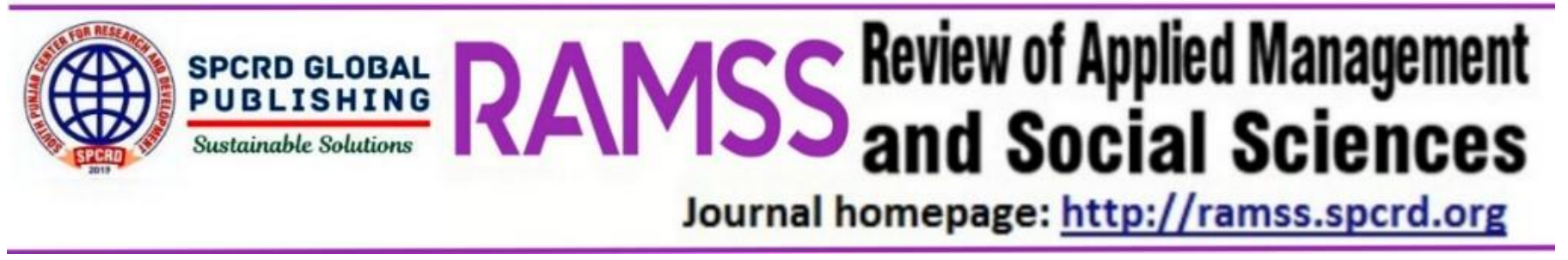

\title{
Parenting Style as a Cognitive Factor in Developing Big-Five Personality Traits among Youth: A Study of Public University in Multan, Pakistan
}

\author{
asfa Ashraf, bamran Ishfaq, ${ }^{\mathrm{c}}$ Muhammad Umair Ashraf, dZahid Zulfiqar \\ aM.Phil Scholar, Department of Sociology, Bahauddin Zakariya University Multan, Pakistan: asfaashraf85@gmail.com \\ bAssociate professor, Department of Sociology, Bahauddin Zakariya University Multan: dr.Kamran@bzu.edu.pk \\ cPhD Scholar (Sociology), GhazaliShafie Graduate School of Government, University Utara Malaysia:umairgujar359@gmail.com \\ dLecturer, Department of Sociology, Multan Post Graduate College Multan:ranazahidzulfiqar@gmail.com
}

Corresponding author's email address: asfaashraf85@gmail.com

\begin{tabular}{|c|c|}
\hline ARTICLE DETAILS & ABSTRACT \\
\hline History: & \multirow{8}{*}{$\begin{array}{l}\text { The present study aimed to investigate the relationship between parenting } \\
\text { styles (authoritarian, authoritative and permissive) and Big-five personality } \\
\text { traits (extraversion, agreeableness, neuroticism, conscientiousness and } \\
\text { openness) among the students of Bahauddin Zakariya University Multan, } \\
\text { Pakistan. For this purpose, a total number of } 281 \text { students from different } \\
\text { faculties (Natural and social sciences) were selected through systematic } \\
\text { sampling technique and the respondents responded to parenting authority } \\
\text { questionnaire (PAQ) by Buri (1991) and Big-five inventory (BFI) john and } \\
\text { Srivastava (1999). Data were analyzed by using SPSS-21 version, and } \\
\text { Pearson correlation ( } \mathrm{r}=\text { o.o1) was applied to find out the relationship, } \\
\text { direction and consistency between predictor and criterion variable. Results } \\
\text { indicated a directly proportional relationship between parenting styles } \\
\text { (authoritarian, authoritative \& permissive) and big five personality traits. }\end{array}$} \\
\hline Accepted: 17 December 2018 & \\
\hline $\begin{array}{l}\text { Available: online } 31 \text { December } \\
2018\end{array}$ & \\
\hline Keywords: & \\
\hline $\begin{array}{l}\text { Parenting styles, Personality } \\
\text { development, Socio-economic }\end{array}$ & \\
\hline status, Youth & \\
\hline JEL C & \\
\hline , $D 71$ & \\
\hline DOI: & \\
\hline
\end{tabular}

\section{Introduction}

Family is a mainstay in a parent and child's personality development because the quality of the relationship between parent-child and their interaction with each other's is considered as a determinant of the child's emotional and behavioral development (Sarmast,2006). The issue of socialization has been observed among human beings through different sources and apiece that makes up the cultural and social personality of the socialized one. McCrae and Costa (1991) have discovered five basic personality dimensions named Big-five personality traits. These dimensions are based on individual differences in thinking, feeling and behaving. These are openness to "Experience, Conscientiousness, Extraversion, Agreeableness and Neuroticism". The feature of openness has been theorized in two ways the first is high capacity to perceive activities and the second is to associate it with the complexity of mental life(Costa \& McCrae, 1985). This feature includes the higher level of logical interest, ability to invent new things, active sense of imagination, giving importance to artistic things, aesthetic interest, emotional, imaginary richness 
and conformism (Batey \& Furnham, 2006; Silvia et al., 2009).

Conscientiousness is an aspect which leads towards dutifulness regarding goal-orientation (van Lieshout,2000). Besides, individuals who have the trait of conscientiousness are more capable of completing their task through selected means. They are considered as organized people who stay dedicated to their goals and feel themselves persevered until the task is completed (Costa \& McCrae, 1998).Extraversion is one of the most positive personality traits in which individuals are different in reward feeling. (Lucas et al.,2008). Extraversion's links have been found to be associated with positive moves (Watson \& Pennebaker, 1989), action and power to interact with new people (Lucas, Le \& Dyrenforth, 2008; McCarae \& Costa, 1991), as well as the power of social actions such as festivity, games, laughing with others or going for movies. The characteristic of agreeableness can be generalized as a distinction in co-operation for combined benefits (Lieshout, 2000) that leads to more pleasant connections. By comparison, the violent expressions are the result of low agreeableness (McCrae and Costa, 1991;Piedmont et al., 1992). The trait of expressive permanency is described as a specific distinction in negative moves and stress reactivity (Matthews, 2004). The miserable condition of an individual can be the reason for less emotional stability as there is a major role of expressive immovability in behavioral control, mildness and stronger sovereignty (Prinzie et al., 2009).

Baumrind (1991) has described three different parenting styles based on demandingness and responsiveness. Authoritarian parenting comprises high demandingness and low responsiveness, while authoritative parenting is based on high demandingness and high responsiveness, whereas permissive parenting encompasses high responsiveness and low Demandingness. Sleddens et al. (20o9) stated extraversion and openness personality trait as a result of authoritarian parenting style; conscientiousness is related to depressing control and elevated parental support. Agreeableness has resulted in terms of higher parental encouragement and affirmative control, whereas neuroticism develops in the dearth of parental warmth (Tomsik \& Ceresnik, 2017; Syed \& Krenke, 2013).

Tomsik and Ceresnik (2017) stated that an individual's personality development, happiness and wellbeing are dependent on an individual's family. Family can also be a predictor of one's poor personality development, violent behaviour. Such type of distress occurs when an individual has poor relationship ties with parents and siblings. As a result, an individual develops negative personality traits, suffers from anxiety and faces many other problems. In family, parental practices used in socializing children are very important. Parenting patterns are the determinant of the child's personality (including thinking, feeling and behaving) development (Prinzieh et al., 2004). Parenting styles are the models for children's training that are formed on the basis of normative interaction and retort to child's behavior (Maddahi et al., 2012). Children have more courage to experience new things when their parents have the ability to provide them with a safe and healthy environment; those parents give preference to their children's needs and desires rather than societal rules and regulations (Miller \& Gerard, 1979).In a study, Hoskins (2014) identified enormous gains in our perception about the influence of parenting behaviors and patterns on adolescent emotional and behavioraloutcomes. Empirical work focusing on the associations between parenting and adolescentoutcomes is necessary due to the fact the impact of parenting throughout influential years continues to affectbehaviors into adulthood. Additionally, there has been great interest paid to the mechanisms that form parenting that then influence adolescent's outcomes. Another research stated that mother's authoritarian parenting is undoubtedlycorrelated with children's aggression; but, the authoritative parenting style is negatively correlated with an adolescent's aggression (Azimi, Vaziri\&Kashani,2012). 
Youth is considered as a complex interlude in personality development that is also recognized as a period of heavy psychological distress in Pakistan (Anwar, Mehmood \& Hanif, 2016). Henceforth, there is a need to find out the proportion of parents and personality development. This study endeavors the previous researches in this field. As far as, there is a paucity of literature that investigates the relationship between parenting style and personality. Earlier researches focused the self-esteem, borderline personality disorder (Infurna et al., 2016), aggression and brunt of extraversion and extra-role performance (Qureshi et al., 2015). The present study aimed at investigating the relationship between parenting styles and personality development in terms of Big-five personality traits in the youth of Bahauddin Zakariya University Multan, Pakistan.

\section{The Objective of the Study}

- To investigate the relationship between parenting styles and Big-five personality traits.

- To find out the direction, consistency of the relationship between parenting styles and Big-five personality traits.

- To find out the socio-economic background and demographic characteristics of the youth of Bahauddin Zakariya University Multan.

\section{The Hypothesis of the Study}

There is a significant relationship between authoritative and permissive parenting style and extraversion, openness, agreeableness personality traits.

Authoritative parenting style is positively associated with extraversion, agreeableness and openness to experience personality traits.

Authoritarian parenting style, conscientiousness and neuroticism are directly proportional to each other.

Permissive parenting is positively related to extraversion and openness to experience personality traits.

\section{Material and Methods}

A cross-sectional research was conducted to find out the relationship between parenting styles and Big-five personality traits. Students of Bahauddin Zakariya University during the year 2017-2019 were the universe of the present research and students of natural and social sciences departments were the targeted population of the study. The questionnaires were distributed among the students in their classrooms by using systematic sampling technique,the questionnaires were filled out and scored by the respondents, and the incomplete ones were discarded, and 281 questionnaires were reviewed. In the end, data were analyzed through SPSS-21 software to find out the relationship between the predictor variable and criterion variable through Pearson correlation.The first part of the questionnaire consisted of sociodemographic information of the respondents while the second part of the questionnaire was based on Parental authority questionnaire scale (PAQ-Buri, 1991); To measure it the parenting style of respondent's parents was used with 30 items and three subscales including authoritative, authoritarian and permissive parenting styles and Big-five inventory (BFI) by John and Srivastava (1999) applied to measure the produced variance due to parenting styles in Big-five personality traits were used which had five subscales including extraversion, agreeableness, openness, neuroticism, conscientiousness.During the process of data collection, in order to get reliable responses, heads of departments were informed and the respondents were informed about the objective and importance of the research.The subsequent descriptive 
table described the socio-demographic characteristics of the respondents in terms of their age/gender/level of education/current living/father's qualification/father's work sector/mother's education/mother work sector/family monthly income/residential ownership/family type/family size/birth order/another house than living.

\section{Demographic Information of the Respondents}

\begin{tabular}{|c|c|c|}
\hline Variables & Categories & $\mathrm{F}(\%)$ \\
\hline \multirow[t]{2}{*}{ Gender } & Male & $140(49.8)$ \\
\hline & Female & $141(50.1)$ \\
\hline \multirow[t]{2}{*}{ Age } & $16-20$ & $60(21.4)$ \\
\hline & $21-25$ & $221(78.6)$ \\
\hline \multirow{3}{*}{$\begin{array}{l}\text { Level } \\
\text { Education }\end{array}$} & M.phil. & $81(28.8)$ \\
\hline & Masters & $85(30.2)$ \\
\hline & B.S & $115(40.9)$ \\
\hline \multirow{4}{*}{ living } & University hostel & $215(76.5)$ \\
\hline & Private hostel & $13(4.6)$ \\
\hline & Relatives & $21(7 \cdot 5)$ \\
\hline & Own house & $32(11.4)$ \\
\hline \multirow{8}{*}{$\begin{array}{l}\text { Father's } \\
\text { qualification }\end{array}$} & Illiterate & $51(18.1)$ \\
\hline & Primary & 3(1.1) \\
\hline & Middle & $24(8.5)$ \\
\hline & Matriculation & $41(14.6)$ \\
\hline & Intermediate & $59(21.0)$ \\
\hline & Graduation & $38(13.5)$ \\
\hline & Masters & $43(15 \cdot 3)$ \\
\hline & Other & $22(7.8)$ \\
\hline $\begin{array}{l}\text { Father's } \\
\text { work sector }\end{array}$ & Governmental & $207(73.7)$ \\
\hline
\end{tabular}




\begin{tabular}{|c|c|c|}
\hline & Semi-governmental & $65(23.1)$ \\
\hline \multirow{11}{*}{$\begin{array}{l}\text { Mother's } \\
\text { qualification }\end{array}$} & Private & $3(1.1)$ \\
\hline & Unemployed & $2(0.7)$ \\
\hline & Other & $4(1.4)$ \\
\hline & Illiterate & $50(17.8)$ \\
\hline & Primary & $23(8.2)$ \\
\hline & Middle & $41(14.6)$ \\
\hline & Matriculation & $72(25.6)$ \\
\hline & Intermediate & 31(11.0) \\
\hline & Graduation & $42(14 \cdot 9)$ \\
\hline & Masters & $19(6.8)$ \\
\hline & Other & $3(1.1)$ \\
\hline \multirow[t]{5}{*}{$\begin{array}{l}\text { Mother's } \\
\text { work sector }\end{array}$} & Governmental & $25(8.9)$ \\
\hline & Semi-governmental & $67(23.8)$ \\
\hline & Private & $24(8.5)$ \\
\hline & Housewives & $152(54.1)$ \\
\hline & Other & $13(4.6)$ \\
\hline \multirow{2}{*}{$\begin{array}{l}\text { Residential } \\
\text { house ownership }\end{array}$} & Owned & $248(86.1)$ \\
\hline & Rented & $33(11.7)$ \\
\hline \multirow{5}{*}{$\begin{array}{c}\text { Family } \\
\text { monthly income }\end{array}$} & $5000-15000$ & $35(12.4)$ \\
\hline & $15001-25000$ & $65(23.1)$ \\
\hline & $25001-35000$ & $66(23.4)$ \\
\hline & $35001-45000$ & $47(16.7)$ \\
\hline & $>45000$ & $68(24.2)$ \\
\hline \multirow[t]{2}{*}{$\begin{array}{l}\text { Place } \\
\text { residence }\end{array}$} & Rural & $91(32.3)$ \\
\hline & Urban & $190(67.6)$ \\
\hline \multirow[t]{2}{*}{ Family type } & Joint & $151(53 \cdot 7)$ \\
\hline & Nuclear & $130(46.2)$ \\
\hline \multirow[t]{3}{*}{ Family size } & $3-8$ & $195(69 \cdot 3)$ \\
\hline & $9-13$ & $68(24.1)$ \\
\hline & $14-18$ & $18(6.4)$ \\
\hline \multirow[t]{3}{*}{ Birth order } & $1-5$ & $220(78.2)$ \\
\hline & $6-9$ & $51(18.1)$ \\
\hline & $10-13$ & $10(3 \cdot 5)$ \\
\hline Another & & \\
\hline \multirow{2}{*}{$\begin{array}{l}\text { house other } \\
\text { living }\end{array}$} & Yes & $131(46.6)$ \\
\hline & No & $150(53 \cdot 3)$ \\
\hline
\end{tabular}

NOTE: $\%$ age in the bracket, $\mathrm{N}=281$

The above-mentioned table displayed the socio-demographic profile of the research participants. 
The first item "Age of the respondent"told that maximum of the respondents $60(21.4 \%)$ reported that they were (16-20) years old while 221(78.6\%) reported that they were (21-25) years old. Second item "Gender of the respondent" reported that there were $140(49.8 \%)$ male and 141(50.1\%) female respondents in the present research. The third item "Level of education of the respondents" maximum of the respondents $115(40.9 \%)$ reported that they were the students of B.S. while $85(30.2 \%)$ respondents reported that they were the students of Masters, but $81(28.8 \%)$ of the respondents reported that they were the students of M.phil. The fourth item "'currently residence" $215(76.5 \%)$ respondents mentioned that they were living in University hostels, 32(11.4\%) respondents said that they were living in their own houses, 21(7.5\%) respondents said that they were living in their relatives; houses. while $13(4.6 \%)$ respondents answered that they were living in private houses. The fifth item was the "father's qualification of the respondent" 59(21.0\%) respondents said that their father's had done intermediate, 51(18.1\%) respondents said that their fathers were illiterate, $43(15.3 \%)$ respondentsmentioned that their father's had done masters while 41(14.6\%) respondents said that their fathers had done matriculation, 38(13.5\%) respondents said that their father's had done graduation, $24(8.5 \%)$ respondents reported that their father's had done middle education, but $22(7.8 \%)$ respondents reported that their fathers had done other qualification and 3(1.1\%) respondents' fathers had done primary education. The sixth item was regarding respondents' "type/ sector of father work" $207(73.7 \%)$ respondents said that their fathers were working in governmental sectors, 65(23.1\%) respondents mentioned their fathers were working in semi-governmental sectors while 4(1.4\%) respondents said that their fathers were working in other sectors, $3(1.1 \%)$ respondents said that their fathers were working in private sectors, but $2(0.7 \%)$ respondents mentioned that their fathers were unemployed. The seventh item "Mothers' qualification" of the respondents. It was reported that $50(17.8 \%)$ respondents said that their mothers were illiterate, $23(8.2 \%)$ respondents mentioned that their mothers were primary passed, 41(14.6\%) respondents incorporated that their mothers had done Middle, 72(25.6\%) respondents answered that their mothers had done matriculation,31(11.0\%) respondents said that their mothers had done intermediate, 42(14.9\%) respondents incorporated that their mothers had done graduation, 19(6.8\%) respondents said that their mothers had done masters and 3(1.1\%) respondents said that their mothers had done other qualification. The eighth item was "Type of sector your mother works" it was disclosed that 152(54.1\%) respondents mentioned that their mothers were housewives, 67(23.8\%) respondents said that their mothers were working in the semi-governmental sector, 25(8.9\%) respondents replied that their mothers were working in the government sector, 24(8.5\%) respondents answered that their mothers were working in the private sector, but $13(4.6 \%)$ respondents mentioned that their mothers were working in other sectors. The ninth item was related with the "Ownership status of the respondent"' 248(88.2\%) respondents replied that they were living in their own houses while 33(12.4\%) respondents mentioned that they were living in rented houses. The Tenth item was related with "family income" it was reported that 68(32.3\%) their monthly income was $>45000$, $66(23.4 \%)$ respondents said that their monthly family income was 25001-35000, 65(23.1\%) respondents answered that their monthly family income was 15001-25000, while 47(16.7\%) respondents reported that their monthly family income was 35001-45000, but 35(12.4\%) respondents mentioned that their monthly family income was 5001-15000. The Eleventh item "Residential Area of the respondent" it was found that $190(67.6 \%)$ respondents were from the urban area while 91(32.3\%) respondents mentioned that they were from the rural area. The Twelfth item was related with "Family size" 195(69.3\%) respondents mentioned that their family size was of 3-8 members, 68(24.9\%) respondents replied that their family size were of 9-13 members while 18(6.4\%) respondents answered that their family size were of 14-18. The Thirteenth item "Birth order in siblings" 220(78.2\%) respondents mentioned their birth order were (1-5), 51(18.1\%) respondents mentioned their birth order were (6-9) while the remaining 10(2.5\%) respondents said that their birth order was (10-13). The Fourteenth item "family type" 151(53.7\%) respondents said that they were living in the joint family system while $130(46.2 \%)$ respondents mentioned that they were 
living in the nuclear family system. The Fifteenth item was "Do your parents have any other house than you are living in?" $150(53.3 \%)$ respondents said that their parents had not any other house than they were living in while $131(46.6 \%)$ respondents mentioned that their parents had another house than they were living in.

The table showed the correlation between parenting styles and big-five personality traits among students of Bahauddin Zakariya University Multan. The table showed that authoritative parenting style had the highest means, also authoritarian parenting style was about 1 grade higher than permissive parenting style while in Big-five personality traits openness personality trait were about 5 grade higher mean than Agreeableness, conscientiousness personality trait had four grades higher mean than neuroticism and extraversion personality traits hadthe lowest mean of four mentioned personality traits.

\section{Pearson Correlation Coefficient}

\section{Relationship between Parenting Styles and Big-Five Personality Traits}

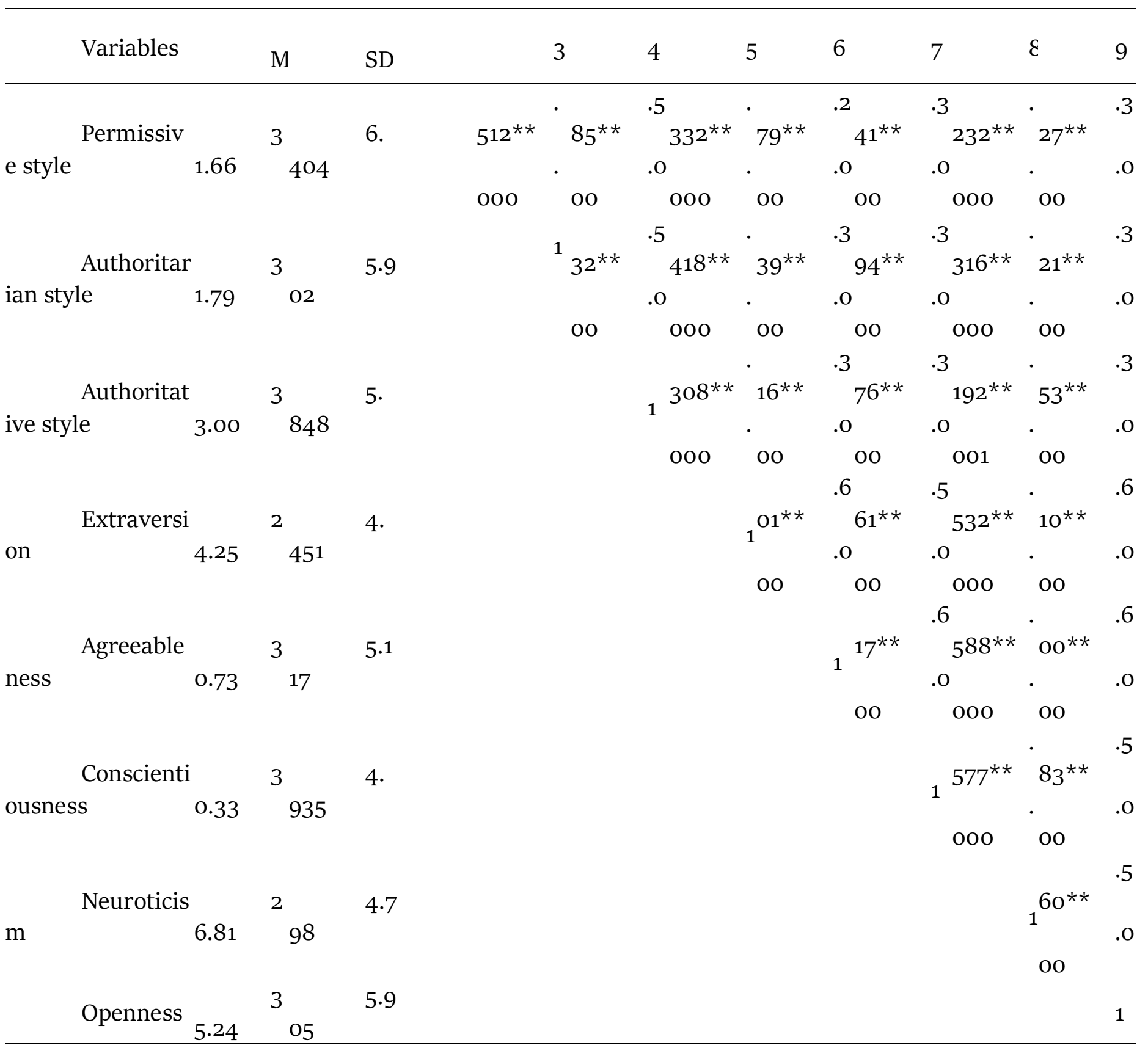


Note: $\mathrm{N}=\mathbf{2 8 1},{ }^{* *}$ Correlation is significant at the 0.01 level, $\mathrm{M}=$ Means SD, Standard Deviation

The table illustrated the distribution correlation between parenting styles and personality typologies among the students of Bahauddin Zakariya University Multan on three categories of parenting styles and five categories of personality. Overall, there was a significant correlation between parenting styles and personality typologies. But there was a significant correlation between authoritarian parenting style with authoritative parenting, extraversion, agreeableness, conscientiousness, neuroticism and openness personality. In terms of Authoritative parenting, there was also a significant correspondence between Extraversion, agreeableness, conscientiousness, neuroticism and openness and authoritative parenting. On the other hand, there was a parallel correlation between extraversion personality and agreeableness, conscientiousness, neuroticism and openness personality traits. Agreeableness traits were also significantly correlated with conscientiousness, neuroticism and openness personality traits. On the contrary, conscientiousness personality was also correlated with Neuroticism and openness personality. Not only conscientiousness was correlated with openness, but Neuroticism traits were also significantly correlated with openness personality traits.

\section{Discussion}

Parenting styles (IV) based on responsiveness and demandingness (authoritarian, authoritative and permissive) and on the other hand, dependent variable (DV) Big five personality traits (extraversion, agreeableness, conscientiousness, neuroticism and openness) were analyzed through the Pearson correlation for the identification of correlation, direction and consistency of the relationship between IV and DV results revealed that there was a significant correlation $\left(\mathrm{p}<0.01^{* *}\right)$ between parenting styles and personality traits. Langenhof, Komdeur and Oldehinkel (2016) stated that there was a significant relationship between parenting styles and personality resemblance $(\mathrm{p}<0.01$ or 0.02$)$ a parent's personality was a correlated with parent-child distinctions (adolescents were different from their parents) the researcher had applied the Pearson correlation on parental personality and children differences with respect to the corresponding personality of parents which was based on mildness \&rejection of parents towards the child. As present results, showed there was a significant correlation between parenting style and personality traits at $\mathrm{P}<0.01^{* *}$. Another study conducted by the Tomšik and Čerešník (2017) stated that children who had been raised up through authoritative parenting style have fewer chances to develop neuroticism traits because these children were highly emotionally stable and categorized as extraversion. Sleddens et al. (2014) indicated that parental warmth behaviour and positive support increased a child's emotional stability. This study also discovered no significant relationship between openness personality trait and parenting styles.Findings from statistical analysis substantiated research hypothesis that was based on previous literature(for instance, Losoya, 1997; Langenhof, Komdeur and Oldehinkel, 2016; Tomšik and Čerešník, 2017). Henceforth, it could be said that parenting styles were the cognitive factors in personality traits.

\section{Conclusion and Suggestions}

This study concluded that there was a significant positive correlation between parenting styles (Authoritarian, Authoritative and Permissive style) and Big-five personality traits among adolescents. Future studies should be conducted to find out the role of socioeconomic status in developing big-five personality traits. This study was comprised ofsmall sample size. Further studies should be conducted on a larger scale. This study also suggested that further studies should be conducted to find out the influence of the peer group and self-efficacy in personality development. 


\section{References}

Anwar, M., Mahmood, B., \& Hanif, M. K. (2016). Mental Health Issues in Young Adults of Pakistan: The Relationship of Narcissism and Self-Esteem With Aggression. Journal of Behavioural Sciences, 26(2).

Azimi, A. L., Vaziri, S., \& Kashani, F. L. (2012). Relationship between Maternal Parenting Style and Child's Aggressive Behavior. Procedia-Social and Behavioral Sciences, 69, 1276-1281.

Batey, M., \& Furnham, A. (2006). Creativity, intelligence, and personality: A critical review of the scattered literature. Genetic, Social, and General Psychology Monographs, 132(4), 355 -429.

Baumrind, D. (1991). The influence of parenting style on adolescent competence and substance use. The Journal of Early Adolescence, 11, 56-95.

Hoskins, D. (2014). Consequences of parenting on adolescenoutcomes. Societies, 4(3), 506-531.

Infurna, M. R., Brunner, R., Holz, B., Parzer, P., Giannone, F., Reichl, C., ... \& Kaess, M. (2016).The specific role of childhood abuse, parental bonding, and family functioning in female adolescents with borderline personality disorder. Journal of personality disorders, 30(2), 177-192.

Langenhof, M. R., Komdeur, J., \& Oldehinkel, A. J. (2016). Effects of parenting quality on adolescents' personality resemblance to their parents. The TRAILS study. Journal of adolescence, 51, 163-175.

Losoya, S. H., Callor, S., Rowe, D. C., \& Goldsmith, H. H. (1997). Origins of familial similarity $\quad$ in parenting: A study of twins and adoptive siblings. Developmental Psychology, 33(6), 1012.

Lucas, R. E., Le, K., \& Dyrenforth, P. S. (2008). Explaining the extraversion/positive affect relation: Sociability cannot account for extraverts' greater happiness. Journal of Personality, 76(3), 385 414 .

Maddahi, M. E., Javidi, N., Samadzadeh, M., \& Amini, M. (2012). The study of relationship between parenting styles and personality dimensions in sample of college students. Indian Journal of Science and Technology, 5(9), 3332-3336.

Matthews, G. (2004). Neuroticism from the top down: Psychophysiology and negative emotionality. In R. M. Stelmack (Ed.). On the psychobiology of personality: Essays in honor of Marvin Zuckerman (pp. 249 -266). New York, NY, US: Elsevier Science.

McCrae, R. R. (1996). Social consequences of experiential openness. Psychological Bulletin, $\quad 120(3), \quad 323$ $-337$.

McCrae, R. R., \& Costa, P. T. (1991). Adding Liebe und Arbeit: The full five-factor model and well-being. Personality and Social Psychology Bulletin, 17(2), 227 -232.

Miller, B. C., \& Gerard, D. (1979). Family influences on the development of creativity in children: An integrative review. Family Coordinator, 28, 295 -312.

multidimensional construct. Journal of Marriage and the Family, 61, 574-587.

Phillips, B. A., Conners, F., \& Curtner-Smith, M. E. (2017). Parenting children with down syndrome: An analysis of parenting styles, parenting dimensions, and parental stress. Research in developmental disabilities, 68, 9-19.

Piedmont, R. L., McCrae, R. R., \& Costa, P. T. (1992). An assessment of the Edwards Personal Preference Schedule from the perspective of the five-factor model. Journal ofPersonality Assessment, 58(1), $67-78$.

Prinzie, P., Onghena, P., Hellinckx, W., Grietens, H., Ghesquière, P., \& Colpin, H. (2004). Parent and child personality characteristics as predictors of negative discipline and externalizing problem behaviour in children. European Journal of Personality, 18(2), 73102.

Prinzie, P., Stams, G. J. J., Dekovi ć, M., Reijntjes, A. H., \& Belsky, J. (2009). The relations between parents ' big five personality factors and parenting: A meta-analytic review. Journal of Personality and Social Psychology, 97(2), 351-362.

Qureshi, S. A., Ashfaq, J., Hassan, M., \& Imdadullah, M. (2015). Impact of extroversion and narcissism 
on in role and extra role performance: Moderating role of impression management motives. Pakistan Journal of Commerce and Social Sciences, 9(1), 96-119.

Sarmast, A. (2006). Relationship between parenting styles and stress coping styles. Symp. Of Natl.

Conf. Psychology \& Society. Islam. Azad Univ. Roudehen, 22.

Silvia, P. J., Nusbaum, E. C., Berg, C., Martin, C., \& O ’Conner, A. (2009). Openness to experience, plasticity, and creativity: exploring lower-order, higher-order, and interactive effects. Journal of Research in Personality, 43, $1087-1090$.

Sleddens, E. F., O’Connor, T. M., Watson, K. B., Hughes, S. O., Power, T. G., Thijs, C., ... \& $\quad$ Kremers, S. P. (2014). Development of the comprehensive general parenting questionnaire for caregivers of 513 year olds. International Journal of Behavioral Nutrition and Physical Activity, 11(1), 15.

Syed, M., \& Seiffge-Krenke, I. (2013). Personality development from adolescence to emerging adulthood: Linking trajectories of ego development to the family context and identity formation. Journal of personality and social psychology, 104(2), 371.

Tomšik, R., \&Cerešník, M. (2017). Adolescent's personality through big five model: the relation with parenting styles. Ad Alta: Journal of Interdisciplinary Research, 7(2). 